\title{
Rethinking the Circuit of Culture: how participatory culture has transformed cross-cultural communication
}

\author{
Bridget Tombleson \& Dr Katharina Wolf \\ Curtin University, Perth, GPO Box U1987 WA 6845 \\ Bridget.tombleson@curtin.edu.au; k.wolf@curtin.edu.au
}

\begin{abstract}
This paper explores the influence of digital communication - and in particular social media - on cross-cultural communication, based on the Circuit of Culture model. Scholarly literature supports the notion that social media has changed the speed at which we communicate, as well as removed traditional (geographical) boundaries around crosscultural campaigns. Since the introduction of digital media, the role of the public relations practitioner has become more strategic in order to maintain relevance with even more diverse - and dispersed - audiences. Large scale campaigns, like the Human Rights Campaign to support Lesbian, Gay, Bisexual, and Transgender (LGBT) rights, have seen messages spread far beyond the country of origin, and with that, demonstrate the ability to affect advocacy campaigns in other countries. The authors argue that instead of acting as cultural intermediaries, public relations practitioners must become cultural curators, with the skills to create meaning from audiences, who are now content creators in their own rights, and encourage a true participatory environment that sees cultural values shared as part of an organic exchange process.
\end{abstract}

\section{Keywords}

Circuit of Culture, participatory culture, hashtag activism, co-creation, cross-cultural communication, cultural curator

\section{Introduction}

The emergence of new communication technologies and platforms has resulted in increased scholarly attention investigating how social media can be used to bridge the digital and cultural divide between different audiences and professional communicators. Public relations and media scholars have argued that the emergence of online technologies have addressed, and potentially even equalised, existing power inequalities between traditionally well-resourced corporations and resource poor activist groups (e.g. Bray, 1998; Bunting \& Lipski, 2001; Coombs, 1998; Heath, 1998; Jaques, 2006; Mazzini, 2004), as well as between western and developing nations (Ali, 2011; Han \& Zhang, 2009; Pamment, 2015). This is arguably particularly relevant within the context of international public relations, as many cross-cultural communication campaigns are no longer country specific, but instead aim to build global support movements. The viral nature of some of these campaigns, like the Human Rights Campaign and Facebook's campaign to support Lesbian, Gay, Bisexual, and Transgender (LGBT) rights, have seen messages spread far beyond the country of origin, highlighting their ability to affect advocacy campaigns in other countries. 
Social media has been used for more than a decade to engage with international audiences and enhance awareness of both corporate and non-government organisations' (NGOs) campaigns and causes. The reasons why audiences and publics choose to participate in social media campaigns have been studied from different angles, such as social listening (Collister, 2016), engagement, behaviour change and hashtag activism campaigns (Chiluwa \& Ifukor, 2015). Pammet (2015) highlights the emerging trend of "diplomatic campaigns taking the form of multilateral, multistakeholder global movements, such as in climate change, human rights, health, anti-terrorism and energy security" (p.2). Recent hashtag activism campaigns, such as \#bringourgirlsback, \#equalityforall and \#blacklivesmatter, illustrate how a high level of social media engagement and participation across traditional, geographical borders has enabled a range of grassroots organisations to leverage (global) campaigns for their own benefit. The authors define hashtag activism as the act of fighting for or supporting a cause with the use of hashtags as primary channel to raise awareness of an issue and encourage debate via social media.

This paper is based on a critical analysis of Facebook's LGBT campaign from a cross-cultural perspective, using the Circuit of Culture framework and applying a participatory culture lens. Ciszek (2013) notes that "participatory culture is the site of convergence of production, consumption, and content" (p. 188). Hence, the authors argue that we need to view the 'traditional' Circuit of Culture through a co-creation and participatory culture lens. As active co-creators, engaged online audiences, such as hashtag activists, create their own artefacts and influence the speed in which culturally constructed meanings evolve and change. Drawing on Jenkins' (2006) concept of participatory culture, whilst analysing Facebook's LGBT campaign, the authors argue that public relations practitioners need to move beyond Bourdieu's (1984) understanding of public relations practitioners as "cultural intermediaries, mediators between producers and consumers who actively create meaning by establishing an identification between products or issues and publics" (Curtin \& Gaither, 2007, p.41), which has - in different forms - been echoed in the public relations literature to date (Edwards, 2012; Hodges, 2006; Schoenberger-Orgad, 2011). Instead, public relations professionals need to become cultural curators, who are equipped to construct meaning from audiences, who have now become content creators in their own right, and encourage a true participatory environment that sees cultural values shared as an organic exchange, rather than a manufactured one.

This paper highlights areas for future study from a cross-cultural perspective. For example, how can how advocacy groups across the globe effectively harness organic movements to support their communications efforts? How can public relations practitioners increase participation in related campaigns that are not driven by them? If organisations like Facebook are turning users into lobbyists for particular causes (Stempeck, 2015), how will advocacy groups be able to leverage this momentum in the future and how can this be done in a transparent, legal and ethical manner (Stempeck, 2015)? 


\section{Literature Review}

\subsection{The Circuit of Culture}

Developed by the Open University cultural studies team towards the end of the last century (Du Gay, Hall, Janes, Mackay, \& Negus, 1997; Hall, 1997) the Circuit of Culture is arguably an expansion of Hall's (1973) traditional encoding-decoding model of communication, extending the creation of meaning to five moments: regulation, production, consumption, representation and identity work together to "create a shared cultural space in which meaning is created, shaped, modified and recreated" (Curtin \& Gaither, 2007, p.38). Within the context of this paper particular attention is paid to identity, consumption and regulation, i.e. those moments that are increasingly influenced by participating, co-creating audiences.

Despite its origins in cultural studies, the Circuit of Culture has been widely applied within the context of public relations (e.g. Al-Kandari \& Gaither, 2011; Ciszek, 2015; Edwards, 2013; Han \& Zhang, 2009; Schoenberger-Orgad, 2011; Terry, 2005; Toledano \& McKie, 2007), most notably by Curtin and Gaither (e.g. 2006; Gaither \& Curtin, 2007), who have used the circuit as a base to develop their cultural-economic model (2005), as well as a practice matrix (2007). Curtin and Gaither's adaptation of the model within a public relations context was motivated by criticism of the prevailing study of international public relations, largely grounded in positivism and predicated on neoliberal economics (Curtin \& Gaither, 2005). Instead, the Circuit of Culture enables the recognition of power, culture and identity, as well as the fluid nature of the construction of meaning, without privileging dominant Western theoretical perspectives. Hence,

the Circuit of Culture redefines public relations as a signifying practice that produces meaning within a cultural economy, privileging identity, difference, and power because of the central role these constructs play in discursive practice (Curtin \& Gaither, 2007, p.110)

However, the authors suggest that in its current form, the Circuit of Culture and relating scholarly work are yet to fully recognise the impact that digital communication and participatory culture have had on international communication and the (co)creation of meaning.

\subsection{Co-creation and public relations}

Based on the work by Hall (1980) and Williams' (1961, 1981), Curtin and Gaither (2007) define culture as "the process by which meaning is produced, circulated, consumed, commodified, and endlessly reproduced and renegotiated in society" ( $p$. 35 ). This definition has as much validity today as it did in 2007 , especially since the rise of social media. The emergence of digital communication and user generated content has further highlighted the limitations of the prevailing ethnocentric lens, which has been the basis for much traditional public relations research to date, privileging the perspective of the western cultural elite (Munshi, 1999). The focus of academic studies into the public relations industry and practices, as well as authors and countries of origin of these research projects, have largely relied on and further emphasised a Western perspective - or what Macnamara (2004) refers to as "Western Myopia" (p. 325). The influence of the United Kingdom and the United 
States of America in public relations scholarship may be slowly weaning (Bardhan \& Weaver, 2011), however, it nevertheless prevails and continues to shape the way in which public relations is understood, taught and practiced. This limits insight into how public relations is conceptualised in non-traditional, Western contexts, as well as how communicators engage audiences across traditional borders.

Furthermore, popular public relations and communication textbooks (e.g. Sriramesh, 2004; Watson, 2014) have traditionally examined cultural contexts of one country at a time, thereby implying geographical border defined differences. However, organic social media campaigns are created around interests and values, as opposed to country-specific preferences. They are often not concerned with (implied) differences in communication practices and cultural variances between countries. Instead, they are focussed on and shaped by human behaviour, the desire to be a part of a group and the (perceived) 'norm' (Correa, Hinsley, \& de Zúñiga, 2010). The rapid emergence of social media and an increased participation rate of many non-Western cultures in organic cross-cultural campaigns are arguably changing the cross-cultural public relations paradigm. Professional public relations actions are often not the driver of these campaigns. However, individual practitioners or organisations may leverage the existing momentum and interest of these movements for organisational and campaign-specific purposes. This is an area that is yet to be fully researched and developed within the public relations discipline, and yet, it offers perhaps one of the greatest opportunities for practitioners developing advocacy campaigns.

Allagui and Breslow (2016) present a positive view in terms of what online communication and new digital platforms can offer to public relations practitioners, concluding that "there is a pervasive discourse in the public relations literature that the use of social media in PR has positive consequences" (p.21) including higher levels of engagement and behavioural impacts. On the other hand, Sanderson, Barnes, Williamson, and Kian (2016) researched the negative effects of public relations social media campaigns by analysing a hijacked hashtag campaign, \#AskJameis. A participatory campaign, \#AskJameis, was used by online audiences for their own agenda, recreating different, non-intended (undesired) meanings, based on the hashtag. Florida State University openly invited football fans and the wider public to submit questions to their award winning quarterback Jameis Winston. However, the attention promptly shifted (inevitably) away from athletic prowess to off-field behaviour. The hashtag hijacking used in \#AskJameis is not uncommon and a frequently observed risk of hashtag campaigns. What may initially appear to be great idea to engage online audiences, hashtags are often interpreted in a different way when audiences are invited to embrace the hashtag, and organisations can very quickly 'lose control' of the intended message. While hashtag activism and slacktivism campaigns have been widely criticised (Chiluwa \& Ifukor, 2015; Hutchins \& Tindall, 2015; Saxton \& Wang, 2013; Veil, Reno, Freihaut, \& Oldham, 2015), social media campaigns, as well as co-creation and sharing of particular ideologies, may reinforce social norms and be the beginning of changing behaviours. Recent studies have indicated that social media hijacking and slacktivism can lead to real change (Veil et al., 2015) as long as they are followed up by practical offline actions (Allagui 
\& Breslow, 2016; Chiluwa \& Ifukor, 2015). This sentiment is supported in this case study.

In the co-creation paradigm, it is this lack - and perceived loss - of control that has resulted in some organisations being reluctant to engage online. Despite mentioning benefits of dialogic online communication for the longevity and authenticity of contemporary organisations, Theunissen (2014) cautions scholars to acknowledge and understand associated potential risks, such as the implications arising from the co-created corporate identity within the digital domain. Valentini (2015) echoes these comments by calling on scholars to critically examine perceived advantages of new and emerging digital tools and platforms, as opposed to generalising that online engagement per se is good for the public relations industry.

Online engagement can offer advantages for professional communicators who are able to harness campaigns that align with organisation or client needs.

Communicators need to recognise that the "co-creational aspect of identity formation then becomes important, highlighting that control over the experience of authenticity does not lie exclusively with the public relations practitioner" (Theunissen, 2014, p. 613). This is an important concept for the public relations industry to recognise, as it is (relatively) unique to the social media environment. The current academic discourse mentions, but rarely analyses the impact of the loss of control that practitioners see in a true participatory world. As illustrated in the \#AskJameis campaign, there is a loss of control in terms of how information will be understood, and also re-purposed. How audiences identify themselves, and issues, is easier to measure when practitioners have small, clearly defined and hence relatively controllable stakeholder groups. This is less the case when social media is used. From the practitioner perspective the audience or stakeholder becomes a lot more difficult to manage - and impossible to control - in the digital world and the recreation of material ultimately changes the organisational narrative (Sanderson et al., 2016, p. 31). On the other hand, the loss of control, can arguably have a positive impact if the 'right' campaign is 'hijacked' (or leveraged) by a public relations practitioner at an appropriate time, and an organic, positive campaign trends in support of the organisation's cause, as will be further illustrated in this paper. The existing literature suggests that social media still sits in an uneasy spot with some public relations practitioners, unable to fully quantify individual channels' effectiveness, or predict outcomes. The full participatory nature of social media will not be utilised until organisations and practitioners understand this loss of control, and - most importantly - become comfortable with it.

\subsection{Public relations and participatory culture}

Jenkins (2009) defines participatory culture as "a culture with relatively low barriers to artistic expression and civic engagement, strong support for creating and sharing one's creations, and some type of informal mentorship whereby what is known by the most experienced is passed along to novices" (p.3). As a part of this culture, participants act no longer as consumers, but actively contribute to and create content (prosumers) (Alaimo, 2015; H. Jenkins, 2006). 
The nature of participatory culture in an online context means public relations campaigns become 'borderless' and that practitioners need to be aware of overall and multiple cultural sensitivities. Ciszek (2013) notes that the value of a participatory audience is not simply determined:

by the size of the audience, but rather from the power to connect with other users, producers, and consumers of this media, to form a public. Participatory media can be particularly empowering for marginalized populations and disenfranchised groups, such as communities of color (e.g., African Americans, Asians, Latinos, Native Americans), religious groups, economically impoverished communities, women and children, immigrant and migrant populations, and sexual minorities. (p.188)

Sanderson et al. (2016) discuss the implications of not listening or understanding perceived issues prior to developing a social media campaign by stating "...that public relations professionals need to be attuned to the "pulse" of the social media audience, to avoid elevating current crises or creating one" (p.31). This implies a high level of environmental monitoring and extensive periods of familiarization with targeted audiences, as well as communication platforms. They also highlight areas of caution within participatory culture, stating that "negative outcomes may be attributable to the growing number of stakeholder voices who can participate in public relations narratives" (p.32).

While calls for critical evaluation of the benefits of digital communication, as well as cautions against common pitfalls, should be taken note of by public relations practitioners, both industry and scholars need to accept that this is the new world in which we operate. In a participatory culture, we all become citizens to some extent, both the audience and the public relations practitioner, and as cultural curators, public relations practitioners need to be looking for opportunities and solutions with digital engagement.

\section{Method}

The aim of this study is to provide in-depth, critical insight into participatory culture within the context of Facebook's LGBT campaign in early 2015. Cutler (2004) highlights the importance of case study research in public relations as useful for areas that do not have current adequate research and literature. Given the existing scarcity of critical, empirical research into cross-cultural communication in the digital age, a single case study approach was chosen, with the aim to provide a deeper understanding of the advantages and challenges of international communication in a digital context, as well as potential opportunities for public relations practitioners who may have so far been reluctant to embrace online communication, or are keen to maximise opportunities provided by the new world in which we operate. The case study approach enables the researchers to draw on multiple sources of evidence both qualitative and quantitative - 'to collect 'rich,' detailed information across a wide range of dimensions" (Daymon \& Holloway, 2011, p. 115). This paper uses inductive reasoning, developing ideas for further research from observations on the case study. 
The researchers considered the following guiding questions in relation to Facebook's LGBT campaign:

1. To what extent did the campaign gain momentum across different countries and cultures?

2. To what extent did the campaign encourage participatory culture?

In understanding the broad, cross-cultural appeal of the campaign (as shown by the data) the researchers also discuss:

3. The extent the campaign affected wider civic action and engagement, e.g. attendance at rallies and other offline supportive events, and

4. How the participatory nature of the campaign influenced identity, consumption and regulation of the shared message.

As the case study method allows for combined descriptive, exploratory, and explanatory approaches (Yin, 2003), this analysis of Facebook's LGBT campaign draws on company statements, first hand observations of online activity by the researchers, news reports, as well as on, and offline, public commentary in regards to the initiative on Twitter, Facebook, blogs and forums. These 'artefacts' provide the basis for documenting the success of the campaign, whilst allowing the researchers to draw on multiple perspectives. As a case study approach includes an in-depth investigation into a specific phenomenon in its natural context (Daymon \& Holloway, 2011), the research team conducted a social media analysis, supported by examination of the \#SCOTUS and \#LGBT hashtags online from 29 March to 29 May 2015 using Radian6 to analyse Twitter, Facebook, comments, images, videos, mainstream news, blogs and forums. Radian6 is a software program that explores social media results from "more than 150 million sites and sources" ("Introduction to Radian6," 2016). The analysis examined the 'LGBT', 'SCOTUS' and 'marriage equality' key words used in the campaign, the number of posts defined by geographical location and trend sentiment (tone of conversation of a post). The Radian6 data gives context to research questions one and two by defining what countries were discussing LGBT rights at the time of analysis and measuring the number of online users discussing 'SCOTUS' and 'LGBT' at the time of the Facebook campaign.

It is important to note that the aim here was not to provide a systematic examination of online activity, nor a statistical data analysis based on quantitative insight, such as number of profile changes (already documented by Facebook), likes and hashtag uses. Instead, the main focus of the Radian6 analysis was to provide context and further depth for the case study, based on content created, sentiment of individual posts, reach and levels of engagement. The Radian6 data also provides further support to Facebook's own figures of the number of users that changed their online profile picture and are members of Facebook LGBT groups.

Whilst the chosen software facilitates access to online data across multiple platforms, including historical information, there are nevertheless limitations to any Radian6 analysis, in that it is an interpretation of the data, based on the researchers' search terms and tools chosen. Insight is limited to the number of social media likes, 
shares and comments with posts using the keywords 'LGBT', 'SCOTUS' or 'marriage equality', in addition to the number of news articles and forums that mentioned the topics. Although Radian6 provides some interpretation of 'sentiment', it does not offer a true context of tone and meaning. Moreover, Radian6 is limited to certain online platforms, with data access depending on privacy settings imposed by the networks owners. For example, access to Facebook data is restricted based on individuals' privacy settings, and accounts are automatically registered in the United States of America, thereby skewing any analysis based on country of origin.

However, given the reach of participatory campaigns and the level of (intended and unintended) engagement, without the use of Radian6, it would be difficult to understand the sheer number of online conversations occurring around the topic and keywords. This is important to understand the role of how participatory social media campaigns are starting conversations, and potentially changing behaviours.

Although the case study approach has the ability to contribute to theory development (Cutler, 2004), it is weak in terms of generalizability of its findings. Although it must be noted that some scholars see great value in the case study approach and the right case study as Flyvbjerg (2006) points out "may greatly add to the generalisability of a case study" (p.226). The authors therefore acknowledge that Facebook's LGBT campaign represents only one particular example of a participatory online initiative, which achieved particular outcomes in terms of levels of engagement and sentiment. Hence, other case studies of digital communication and online activity may draw contradictory conclusions to those made here.

\section{Case study}

The participatory social media LGBT campaign was run by Facebook in April 2015 in support of the US Supreme Court's ruling to legalise same-sex marriage. This campaign was adopted by more than 26 million people worldwide (Dewey, 2015), with more than 1 million users visually expressing their support within the "first few hours" (Matias, 2015). As a part of this campaign Facebook users adopted a transparent 'rainbow flag' across their own profile picture, aided by a photo-editing "Celebrate Pride" tool that Facebook launched to enable its users to publicly demonstrate their support of marriage equality (in America). Although basic in its form, this is an example of participatory culture where the audience is in part, a cocreator of content, and implicit in the message being shared. Their personal investment in terms of time and resources may be limited and may even appear tokenistic, but it nevertheless demonstrates some level of commitment and encourages further discussion of (political) views and values.

The expanded platform campaign run by the Human Rights Campaign (HRC) on Twitter saw \#LBGT and \#SCOTUS trend across social media (not just on Facebook) and in the mainstream press. Key terms used during the analysed period can be seen in the Wordcloud created in Radian6 (Figure 1). 

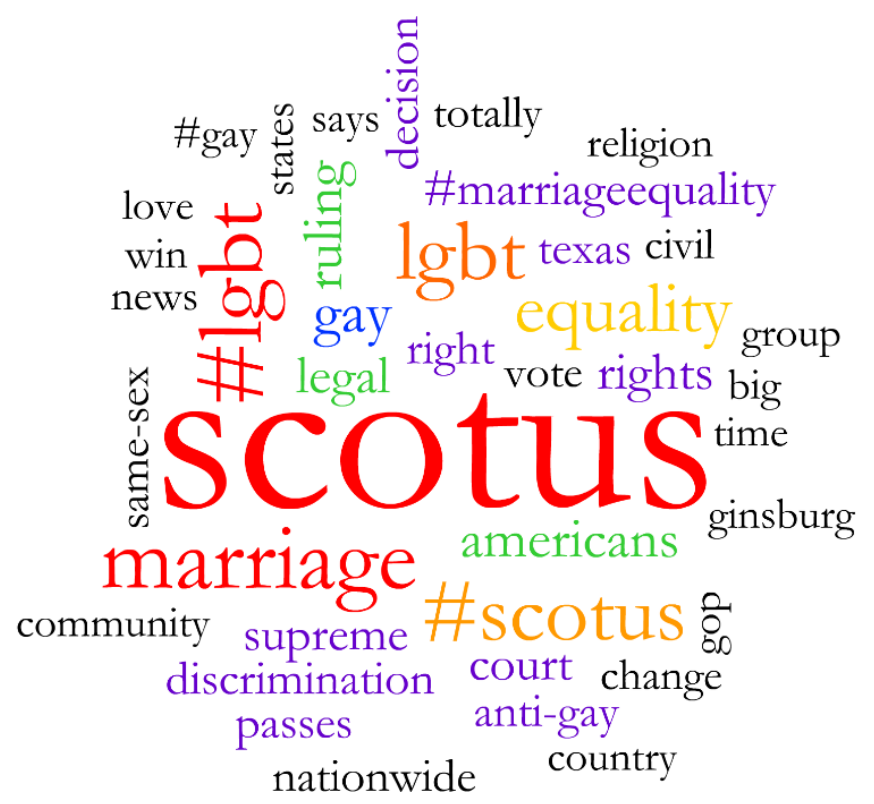

Figure 1. Wordcloud of 'SCOTUS' and 'LGBT' keyword during Facebook LGBT campaign 29 March to 29 May 2015, on Twitter, Facebook, comments, images, videos, news, blogs and forums.

Facebook's decision to publicly support the US Supreme Court same-sex marriage decision is arguably an example of an organic cross-cultural campaign. The campaign was not devised by any particular advocacy group, nor was it specifically targeted at any particular geographic location or stakeholder group, and yet, the campaign was picked up and leveraged by a number of LGBT advocacy groups across the globe. The Human Rights Campaign was the most notable and used the \#SCOTUS hashtag trend to buy promoted tweets during that period (Heine, 2015). Human Rights Campaign marketing director explained to Adweek:

It's a strategy that mixes with organic and promotion on multiple platforms. And it's about working with established [social personalities], which elevates your visibility on any channel. (quoted in Heine, 2015)

The \#SCOTUS campaign generated discussion much further than the original US Supreme Court ruling with 236,6011 online posts occurring during the analysed period around the keyword 'LGBT' (Figure 2). In addition to this, a search of only the term 'LGBT' saw a broader online discussion occurring around homosexual rights, marriage equality and the meaning of sexuality highlighting the ability of HRC's campaign to leverage the discussion into a broader, and cross-cultural, conversation. Some brands have already shown they are leveraging current events to further their own social media agenda with great success, for example Oreo's "You can still dunk in the dark" campaign, following the 2013 Super Bowl black out (Allagui \& Breslow, 2016). As pointed out by Allagui and Breslow (2016) this style of campaign takes advantage of timely events and may not be part of the organisation's original digital storytelling strategy, but inserts itself into current events, and hence the relevance of the audience. 


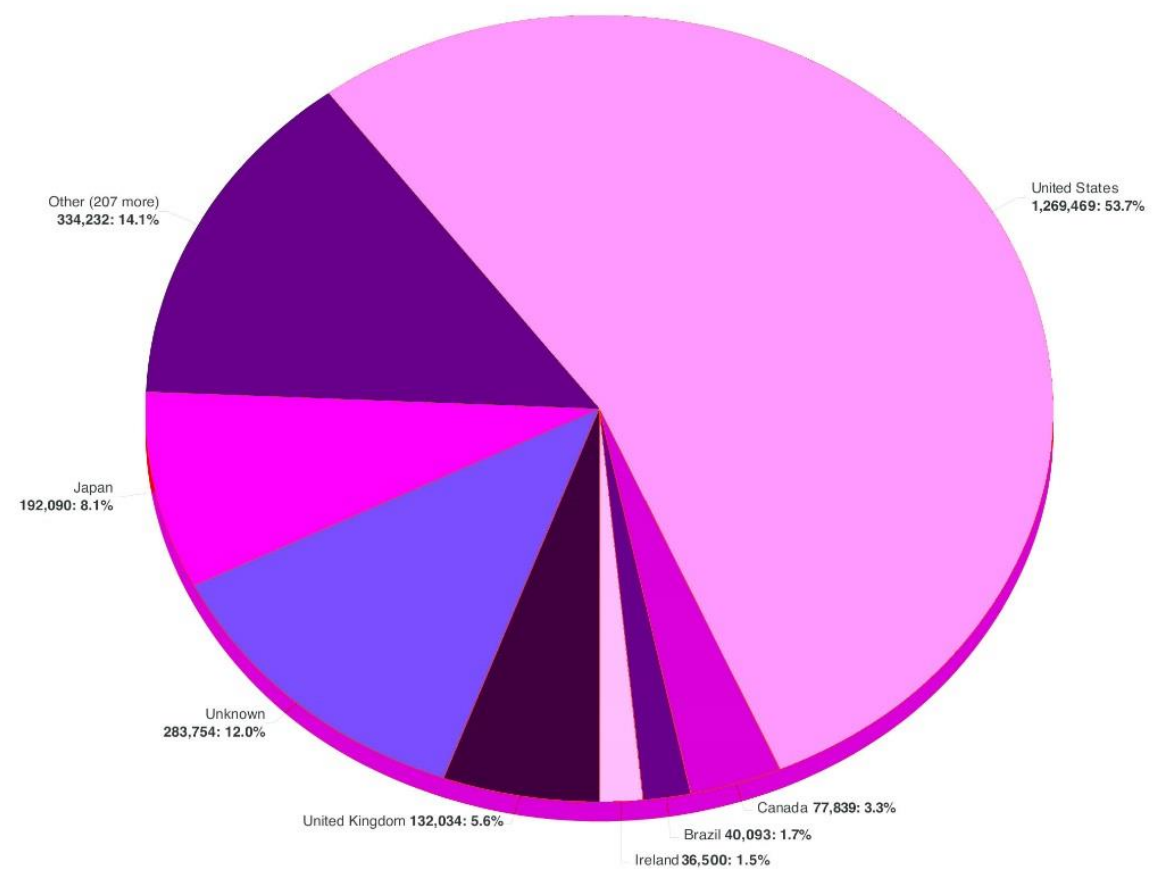

Figure 2. 'LGBT' keyword use by Region during Facebook LGBT campaign 29 March to 29 May 2015, on Twitter, Facebook, comments, images, videos, news, blogs and forums.

Dewey (2015) states that "Facebook itself has found that people tend to change their profile pictures in response to their friends' picture changes", indicating peer influence. These findings are supported by State \& Adamic's (2015) analysis of Facebook's Equal-Sign Profile Pictures campaign, which illustrated that most "individuals changed their profile picture to a variant of the equal sign only after observing several of their friends do it first" (p. 1749). Both these studies emphasise the role of peer influence, as well as the relative risk early adopters are exposed to when challenging the status quo.

Kaplan (2014) quotes Philip Howard of the Digital Activism Research Project at the University of Washington in stating that there is no longer any need to distinguish between online and offline activism. In participatory culture this is an important moment as the two should, and do, feed into one another. At the very heart of public relations in the age of social media is the ability for any campaign, strategic or organic, to target audience(s) "in the context of community building and community relationships” (Allagui \& Breslow, 2016, p.28). Allagui \& Brewslow's study furthermore emphasises that online conversations generated by these campaigns are far richer in providing public relations practitioners with an insight into how audience sentiment is changing. In contrast, traditional measures like media impressions, likes and retweets alone provide a very limited snapshot and fail to measure actual engagement.

\section{Findings and discussion}

5.1 To what extent did the Facebook LGBT campaign gain momentum across different countries and cultures?

Based on the Radian 6 analysis, a total of 16,005 social media posts were shared on Twitter and Facebook using \#SCOTUS and \#LGBT during the campaign period from 
29 March to 29 May 2015 (see Figure 3). This did not include mainstream news posts.

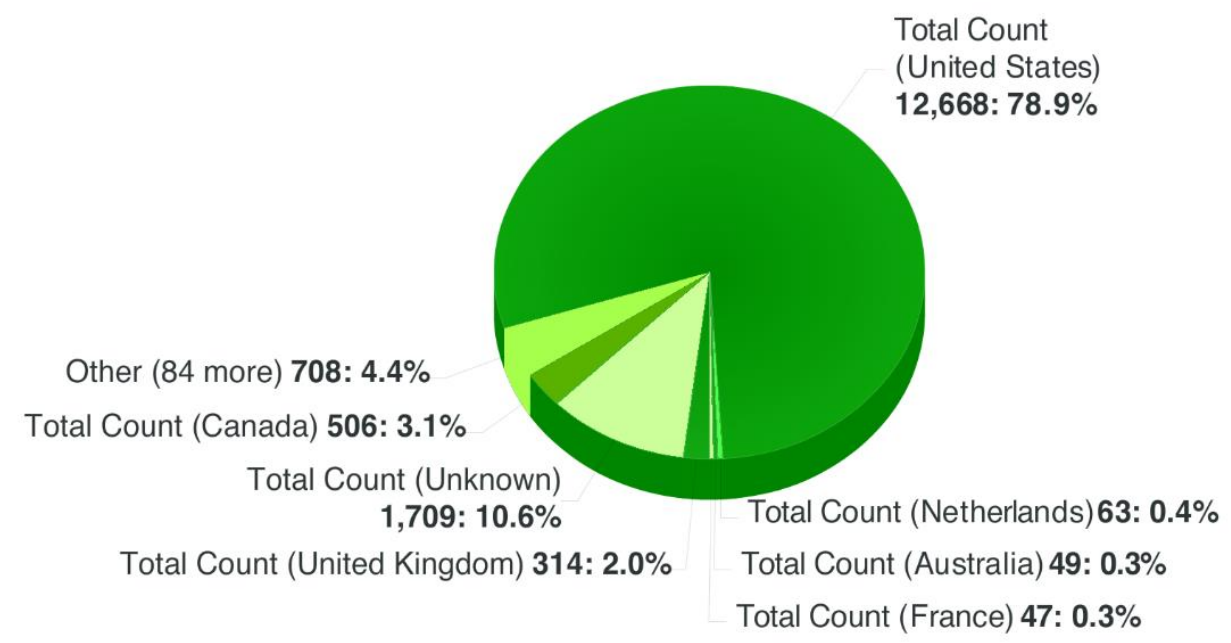

Figure 3. Total number of social media posts on Twitter, Facebook, comments, images, videos, news, blogs and forums for \#SCOTUS and \#LGBT campaign divided by region 29 March to 29 May 2015.

The majority of the posts measured in Radian 6 were on Twitter with a total of 14,359 posts. Facebook recorded a total of 1,178 related posts during this time. Additional key terms used in relation to the campaign included marriage, equality, Americans, marriage equality and ruling. As previously mentioned, total posts for the 'LGBT' keyword at the time were 236,6011 (Figure 2) and during the same period the term 'marriage equality' saw more than half a million posts trend (Figure 4) on the subject, thereby highlighting a high level of engagement.

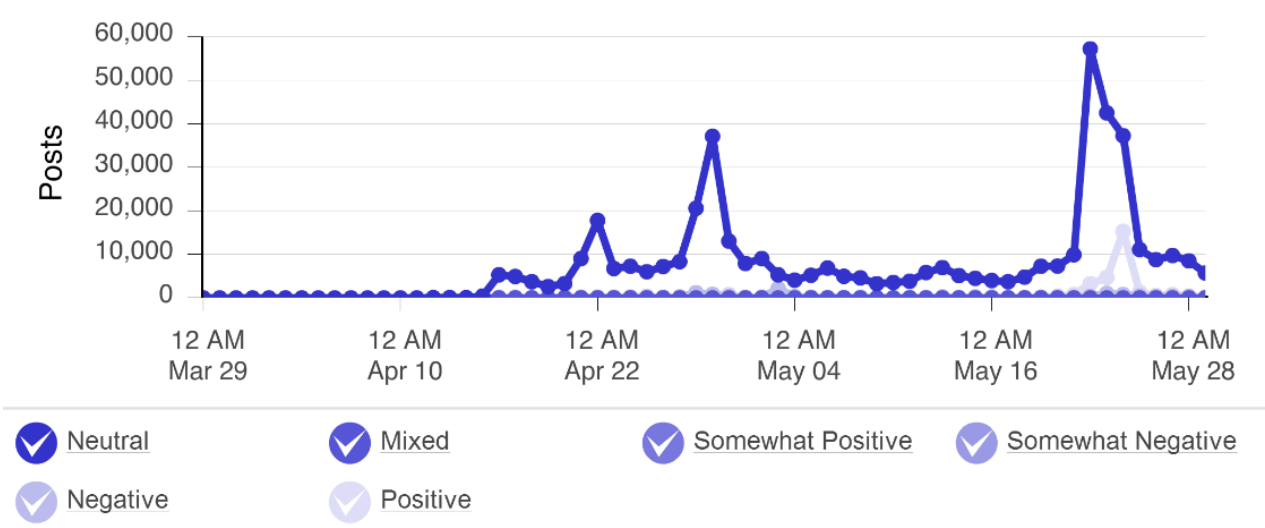

Figure 4. Number of posts and sentiment of 'marriage equality' keyword during Facebook LGBT campaign 29 March to 29 May 2015, on Twitter, Facebook, comments, images, videos, news, blogs and forums. 
The software analysis does not indicate how many users changed their Facebook profile picture during this period. However, according to Facebook's own data more than 26 million users adopted the rainbow flag tool/ profile picture (Dewey, 2015). This indicates that the overall level of engagement with the campaign was significantly higher number than the Radian6 analysis indicates.

The countries involved in reposting or producing material around \#SCOTUS and \#LGBT during this campaign included (in descending order): United States, Unknown, Canada, United Kingdom, Netherlands, Australia, France, Ireland, Greece and Morocco (see figure 3). The United States was the largest country involved in this campaign as it was a US-led campaign and due to the fact that Facebook users are automatically recorded as being located in Northern America. However, the representation of geographically dispersed countries like Morocco, Australia, Greece and the Netherlands indicates the global appeal of the campaign. Furthermore, a Radian6 data analysis based on the LGBT keyword saw the addition of high levels of engagement in Japan and Brazil.

Radian6 data was used to compare the LGBT campaign with other recent high profile hashtag campaigns during their peak period:

\begin{tabular}{|c|c|c|c|c|}
\hline Campaign & Hashtag & $\begin{array}{l}\text { Number of social } \\
\text { media mentions* }\end{array}$ & $\begin{array}{l}\text { Countries trending } \\
\text { location }\end{array}$ & Time Period \\
\hline $\begin{array}{l}\text { Bring our } \\
\text { Girls Back }\end{array}$ & \#BringourGirlsBack & 86,476 & $\begin{array}{l}\text { US, Nigeria, UK, } \\
\text { South Africa, } \\
\text { Netherlands, Brazil, } \\
\text { Canada, 170+ other } \\
\text { countries }\end{array}$ & $\begin{array}{l}15 \text { April - } 15 \\
\text { June } 2014\end{array}$ \\
\hline $\begin{array}{l}\text { Black Lives } \\
\text { Matter }\end{array}$ & \#BlackLivesMatter & 4,896 & $\begin{array}{l}\text { US, Canada, UK, } \\
\text { Australia, } \\
\text { Netherlands, Iran, } \\
\text { Brazil, }+29 \text { other } \\
\text { countries }\end{array}$ & $\begin{array}{l}13 \text { July }-13 \\
\text { Sept } 2013\end{array}$ \\
\hline $\begin{array}{l}\text { US Supreme } \\
\text { Court Ruling }\end{array}$ & \#SCOTUS \#LGBT & 16,005 & $\begin{array}{l}\text { United States, } \\
\text { Canada, United } \\
\text { Kingdom, } \\
\text { Netherlands, } \\
\text { Australia, France, } \\
\text { Ireland, Greece and } \\
\text { Morocco, +84 } \\
\text { countries }\end{array}$ & $\begin{array}{l}29 \text { March to } \\
29 \text { May } 2015\end{array}$ \\
\hline $\begin{array}{l}\text { Marriage } \\
\text { Equality }\end{array}$ & \#LGBT & 236,6011 & $\begin{array}{l}\text { United States, } \\
\text { Canada, Brazil, } \\
\text { Ireland, Japan, UK, } \\
\text { and }+207 \text { countries }\end{array}$ & $\begin{array}{l}29 \text { March to } \\
29 \text { May } 2015\end{array}$ \\
\hline
\end{tabular}

* (Twitter, Facebook, comments, images, videos, news, blogs and forums)

Table 1. Hashtag comparison of LGBT campaign against global campaigns.

The reach of the initial \#SCOTUS campaign was moderate compared to \#BringOurGirlsBack. However, the broader marriage equality campaign showed a significant reach in online discussion and engagement. In addition the number of countries discussing marriage equality (more than 210 countries) at the time was significantly higher than the other successful hashtag campaigns, indicating the global appeal of the campaign - beyond the initial US Supreme Court decision. 
Discussions using the \#SCOTUS \#LGBT hashtag were, in the majority, neutral to positive (see Figure 5), which is arguably not surprising given the rapidly increasing groundswell and support for the campaign. However, the Radian6 analysis of sentiment does not capture the overall positive sentiment that was shown by millions of people by changing their profile picture to 'celebrate pride'. The question also arises if any opposing or critical views were effectively drowned out. Some audiences may have been reluctant to share their views due to the high visual levels of support for the LGBT campaign.

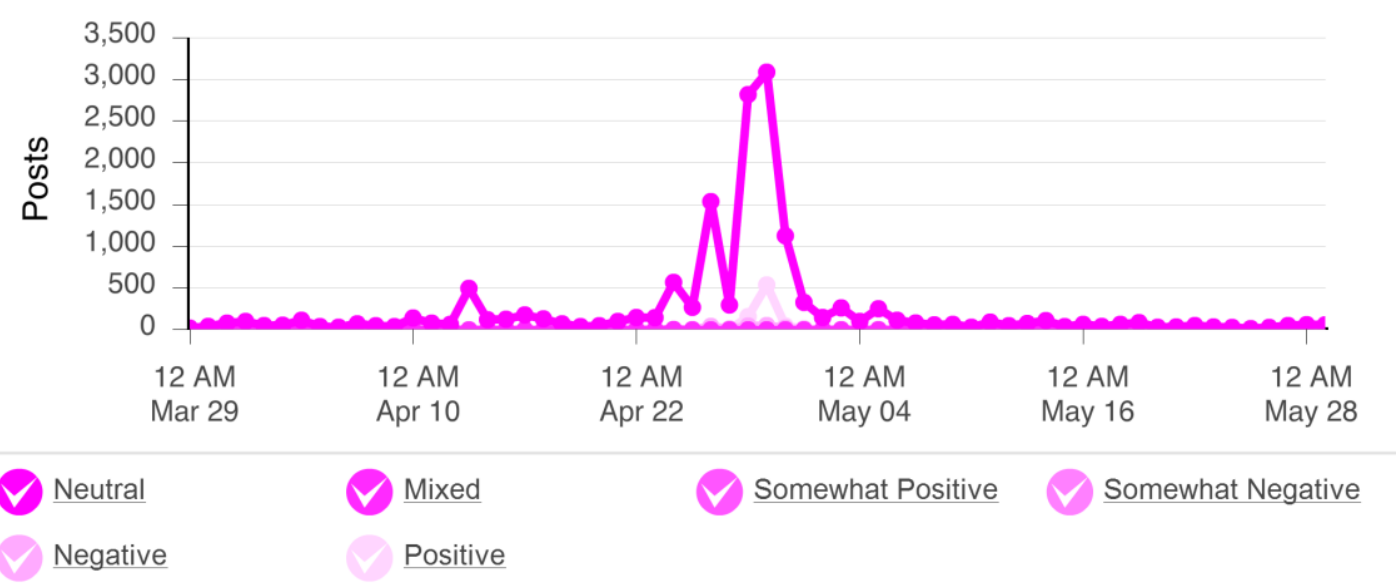

Figure 5. \#SCOTUS and \#LGBT sentiment on Facebook and Twitter campaign 29 March to 29 May 2015.

\subsection{To what extent did the campaign encourage participatory culture?}

The Radian6 analysis around the \#SCOTUS hashtag displayed high levels of online engagement. The top post during the analysed period attracted 200 unique comments. The broader discussions around the keywords used during this period generated in excess of half a million posts related to marriage equality, LGBT, gay rights, discrimination and religious discussions, spanning from the United States to Australia and from Canada to the United Kingdom and beyond.

Advocacy campaigns using social media are particularly effective due to the personal storytelling aspect that is able to be shared on the platform. Allagui and Breslow (2016) state that "it is through the story that members of the target audience not only become aware of and interested in the campaign, but become engaged with the campaign" (p.23). Facebook's support of the LGBT campaign was not solely a stand-alone message being shared on a social media site; instead, multiple, personal stories emerged alongside the campaign, highlighting triumph and adversity, as well as raw emotions. Esurance was one example of an organisation that aligned with the message and used the US Supreme Court decision to launch an advertising campaign, using children to tell the story that everyone's dreams are equal (McLaughlin, 2015). However, audiences are becoming increasingly cynical about organisations' underlying intentions. Alongside the Facebook LGBT rainbow flag campaign a number of conspiracy theories emerged, pointing to Facebook tracking moods and sentiment for their own (commercial) benefits (Matias, 2015). As 
Facebook has a large, specialised data analysis centre, it would arguably be more of a surprise if the network failed to track civic action to build its understanding of how groups of citizens organize online. According to Matias (2015) Facebook used the previous 2013 Human Rights Campaign to analyse how participation spreads and if "groups of citizens can organise online - and how that collective activity affects larger social movements". He points to the ongoing scholarly debate around the effectiveness of profile-image campaigns, which have frequently been dismissed at 'token gestures', but concludes that by looking at the data from the 2015 rainbow flag campaign it is hard to "dismiss online activity as inconsequential".

\subsection{To what extent did the online campaign affect wider civic action and engagement?}

Allagui and Breslow (2016) argue that for truly participatory initiatives "social media campaigns must drive target audiences towards some form of offline engagement, thus optimizing the changes that a campaign goes viral across a broad spectrum of the target audience" (p.24). Hence, the question that arises from this case study is if online participation, however small, increases the likelihood of participants to take part in further civic action, such as the signing of petitions, the donating of money and participation in rallies. Without the ability to track individual participants' actions it is arguably challenging to substantiate any claims of further activity on a global scale. However, traditional media reports and first hand social media accounts suggest high levels of engagement, with reports that in London tens of thousands of people took to the streets a day after the US court ruling to legalise gay marriage ( $\mathrm{L}$. Jenkins, 2015). A further 60,000 people paraded in Dublin (AFP, 2015), and record numbers of demonstrators were seen across the US and Paris (Associated Press \& Klausner, 2015), as well as in the Philippines (Teves, 2015).

These rallies were not initiated by Facebook, nor directly linked to its LGBT campaign. However, it can be argued that the Facebook LGBT campaign increased awareness, and hence potentially participation rates of people involved in supportive rallies across the globe. The Facebook LGBT exposed social media users to the Supreme Court ruling and invited them to publicly share their support, by offering users a low involvement opportunity to express their support by adopting the rainbow flag as part of their profile picture. However, the Facebook campaign cannot be isolated as the sole cause of this, as coverage of the US court decision itself and subsequent media attention and commentary equally supported the viral nature of the message. The overall shift in awareness and active engagement is supported by Facebook's own data, which illustrates growing support for marriage equality over the past decade, based on significantly increased membership in LGBT Facebook groups since 2008 (Matias, 2015).

\subsection{How did the participatory nature of the campaign influence identity, consumption and regulation of the shared message?}

Within the context of this paper particular attention is paid to identity, consumption and regulation, i.e. those moments that are increasingly influenced by actively participating, co-creating audiences. According to Curtin and Gaither (2007) identities are "social constructions emerging from discursive practices" (p. 168), i.e. they are continuously shaped by the world around us, and are often constructed and defined by what we are not (e.g. in the context of this case study, values we may not 
agree with). Within the context of the Circuit of Culture consumption is not understood in its common, narrow sense of consuming a product or service, but refers to "how publics make use of a cultural artefact, such as a campaign issue or product" (p.138) as part of their everyday lives. As such, online engagement and exposure to different views, values and campaigns shapes audiences' ways of interaction and making sense of the world around them. For example, the rainbow flag tool provided by Facebook can mean diverse things to different users, who may adopt the new profile image to proudly state their existing support for marriage equality, or may feel pressured to follow suit in adopting the rainbow flag because a large number of their friends and acquaintances have already done so. However, either way, the rainbow flag tools provides a low investment opportunity to publicly redefine one's identity by expressing support via the personal profile image, either by simply overlaying the existing profile with the flag or becoming more creative and expressive in expressing one's support (or lack thereof). Finally, regulation may be often associated with governments and law enforcement agencies. However, within the context of the Circuit of Culture it is understood as much broader, based around the "constant power struggle between various entities attempting to define the social, moral, and cultural norms of society" (p.52). Social movement and mass mobilization campaigns arguably facilitate debate and consequent power struggles, by challenging the status quo and thereby shaping what is considered acceptable within a given society. Online movements, like the multiple marriage equality sub-groups, have the ability to challenge, influence and ultimately alter norms across traditional, geographical and language boundaries; in this case by using a ruling that is essentially US-based to influence change (to various extends) globally.

Traditional models that use an overall culture's identity based on national borders (see e.g. Geert Hofstede's Cultural Dimensions Hofstede, 2016) to determine participation rates are now arguably very outdated as they fail to take into consideration how social norms can change as a result of online campaigns. Some of these changes can be peer led, but are also based on the sheer number of people sharing their views, even when this can be dangerous in some countries and cultural contexts. In fact, one may argue that the act of publicly sharing a view or standpoint contains a level of risk in any cultural context. As State and Adamic (2015) emphasise: engaging "in a behaviour that challenges the status quo carries inherent risks, from the minute - a quarrel with one's otherwise-thinking friends - to the lifethreatening, as experienced by activists in a political movement challenging a repressive regime" (p.1741). As a part of the Circuit of Culture regulation is an important consideration, but is it becoming less important when social media movements are changing social norms at a faster rate than seen previously. Social media and online communication provide access to likeminded people across the globe, hence redefine the traditional understanding of peers by exposing online users to influencers well beyond the traditional geographical limitations and enable them to seek out new memberships based on interests and perspectives.

The concept of consumption in the Circuit of Culture is also changing at a rapid rate due to the use of social media. How audiences 'consumed' the message of the \#SCOTUS \#LGBT campaign in 2015 is very much wrapped up in the concepts of 
identity and regulation. Even two-way models of communication in public relations fail to fully recognise the co-creation and re-purposing of online campaigns. The State and Adamic (2015) study identified the process of complex diffusion within the context of Facebook's 2013 'equal sign' campaign in support of same-sex marriage. Within this context they found "the process in which the likelihood to engage in activism increases with the observation of other individual's activism" (p.1741). In the case of the LGBT campaign, consumption from a cultural perspective is still relevant, but dependent on audiences' friends and exposure to different world-wide views. Due to the widespread use of the rainbow flag tools, Facebook users became consumers of the LGBT campaign via their newsfeed, hence increasing exposure to the issue, as well as the likelihood of perceived (peer) pressure to change their own profile image - and to potentially take further action offline.

Despite the criticism of the extant scholarly literature for being overly positive in regards to the use of social media in the public relations context (Valentini, 2015), the authors argue that due to its ubiquitous nature public relations practitioners need to pay attention to digital communication. Even though particular clients or campaigns may not warrant a digital campaign or the use of social media channels, listening to online conversations has become a crucial element of every communicator's job description. More importantly, as scholars we need to move beyond the argument of if we use social media, but instead focus on how we can use it effectively. Social media campaigns are changing the speed at which social norms are adopted, as well as audiences' understanding of their own identities. This in turn is affecting cross-cultural communication and as public relations practitioners, we need to embrace participatory culture, and allow audiences to be co-creators, and help shape our campaigns.

\section{Conclusion}

From this case study, the authors suggest that advocacy-based public relations activities can benefit from citizen/advocacy led social media campaigns. Valentini (2015) asserts that "the use of social media is not necessarily as beneficial to either organisations or publics as depicted", pointing to the fact that essentially "social media exists because of interactions and exchanges of opinions among users" (Valentini \& Kruckeberg, 2012, p. 176). However, this view assumes that social media is an entity that can be separated from the daily tasks a public relations practitioner undertakes. If we view social media as part of the cross-cultural world in which we operate, it becomes a critical listening tool that can be leveraged for those able to strategically align business goals with audience sentiment.

Allagui and Breslow (2016) concluded that "the effective use of social media is disrupting the PR campaign cycle" and that the traditional PR campaign may be "displaced by social media campaign tactics which belong to an entirely different ecosystem where the act of sharing social media content generates publicity in lieu of a campaign event" (p.20). This is certainly true in areas where the public wants to participate and organically contribute to the promotion - or even the execution - of the campaign. Hence the role of the public relations practitioner becomes more strategic in nature as it requires an ability to think laterally and bring together pieces 
of information and apply them to cultural situations as they arise. An increased focus on social listening and leveraging campaigns that are already happening, may better serve some public relations campaigns in the future, by ensuring communication becomes more authentic and relevant. We therefore argue that the role of the public relations practitioners needs to increasingly shift from cultural intermediary to cultural curator of information.

The emergence of the internet has been hailed as a power levelling tool between traditionally resource poor activist groups and corporations (Coombs, 1998; Jaques, 2006), as well as between developing nations and first world countries (Ali, 2011). There is no denying that social media allows its citizens to participate more actively in democratic processes. We may still see some citizens of countries with high-levels of internet surveillance self-censoring for security reasons. However, as more people of influence in their network show support, they may become more tolerant or courageous enough to openly support certain causes themselves. Ali (2011) describes this as a softening of ideas, "gradually brought along to be comfortable with new ideas and actions" (p.9). The debate around social media's 'true' effectiveness will continue in the absence of longitudinal data on cultural and policy changes. However, in the meantime even these small changes in attitudes may affect public relations campaigns and in turn, communication strategies of in particular NGO and not-for profit groups. The Circuit of Culture is a highly relevant and useful model for public relations practitioners to use in the context of crosscultural communication. Building on Du Gay et al.'s (1997) model and Curtin and Gaither's consequent work (2005; 2006; 2007; Gaither \& Curtin, 2007), the authors suggest that the Circuit's five moments have become even further interlinked with the emergence of online communication and co-created campaigns. Therefore, the Circuit of Culture model should be viewed and (re)examined through a participation lens, thereby acknowledging how cross-cultural communication has been redefined and evolved within the context of digital communication.

Valentini (2015) states that research indicates public relations practitioners, particularly practitioners working for organisations, use social media for information dissemination rather than a collaborative platform. While this may be reflected in the current scholarly literature, leveraging social media sentiment when it is not related to a practitioner-led campaign is difficult to measure and may not be captured in the current research. Furthermore, online monitoring and evaluation of public relations efforts have to date been largely focused on click-through rates and likes. Software programs, analytical tools and - arguably most importantly - practitioners' skills are still evolving and only slowly moving towards the ability to provide more meaningful insight into levels of engagement and ultimately the success of communication efforts and public relations campaigns. Public relations as an industry needs to fully understand how to utilise the participatory nature of social media or we will forever be 'on the fringes' of the social media movement. This moment presents many areas for researchers to capture the true-value of strategic public relations activities, responding to the environment and leveraging opportunities as they arise. 



\section{References}

AFP. (2015). Thousands celebrate Dublin Pride after marriage vote. MSN News. Retrieved from: http://www.msn.com/en-us/news/world/thousands-celebrate-dublin-pride-aftermarriage-vote/ar-AAce2od

Al-Kandari, A., \& Gaither, T. K. (2011). Arabs, the west and public relations: A critical/cultural study of Arab cultural values. Public Relations Review, 37(3), 266-273. doi: http://dx.doi.org/10.1016/j.pubrev.2011.04.002

Alaimo, K. (2015). How the Facebook Arabic Page "We Are All Khaled Said" Helped Promote the Egyptian Revolution. Social Media + Society, 1(2). doi: $10.1177 / 2056305115604854$

Ali, A. H. (2011). The Power of Social Media in Developing Nations: New Tools for Closing the Global Digital Divide and Beyond. Harvard Human Rights Journal, 24, 185-241.

Allagui, I., \& Breslow, H. (2016). Social media for public relations: Lessons from four effective cases. Public Relations Review, 42(1), 20-30. doi: http://dx.doi.org/10.1016/j.pubrev.2015.12.001

Associated Press, \& Klausner, A. (2015). Millions flock to pride events across America just days after the Supreme Court legalizes gay marriage in all 50 states. Daily Mail, (29th June). Retrieved from: http://www.dailymail.co.uk/news/article3142508/Millions-flock-pride-events-globe-just-days-Supreme-Court-legalizes-gaymarriage-America.html

Bardhan, N., \& Weaver, C. K. (2011). Public relations in global cultural contexts. Multiparadigmatic perspectives. New York: Routledge.

Bordieu, P. (1984). Distinction: A social critique of the judgement of taste (R. Nice, Trans.). Cambridge, MA: Harvard University Press.

Bray, J. (1998). Web wars; NGOs, companies and governments in an internet-connected world. Greener Management International, 98(24), 115-130.

Bunting, M., \& Lipski, R. (2001). Drowned out? Rethinking corporate reputation management for the Internet. Journal of Communication Management, 5(2), 170-178.

Chiluwa, I., \& Ifukor, P. (2015). 'War against our Children': Stance and evaluation in \#BringBackOurGirls campaign discourse on Twitter and Facebook. Discourse \& Society, 26(3), 267-296. doi: 10.1177/0957926514564735

Ciszek, E. L. (2013). Advocacy and Amplification: Nonprofit Outreach and Empowerment Through Participatory Media. Public Relations Journal, 7(2), 187-213.

Ciszek, E. L. (2015). Bridging the gap: Mapping the relationship between activism and public relations. Public Relations Review, 41(4), 447-455. doi: http://dx.doi.org/10.1016/j.pubrev.2015.05.016

Collister, S. (2016). Algorithmic public relations. In J. L'Etang, D. McKie, N. Snow, \& J. Xifra (Eds.), The Routledge Handbook of Critical Public Relations (pp. 360-271). Oxon: Routledge.

Coombs, W. T. (1998). The internet as potential equalizer: New leverage for confronting social irresponsibility. Public Relations Review, 24(3), 289-303.

Correa, T., Hinsley, A. W., \& de Zúñiga, H. G. (2010). Who interacts on the Web?: The intersection of users' personality and social media use. Computers in Human Behavior, 26(2), 247-253. doi: http://dx.doi.org/10.1016/j.chb.2009.09.003

Curtin, P. A., \& Gaither, T. K. (2005). Privileging identity, difference, and power: The circuit of culture as a basis for public relations theory. Journal of Public Relations Research, 17(2), 91-115.

Curtin, P. A., \& Gaither, T. K. (2006). Contested Notions of Issue Identity in International Public Relations: A Case Study. Journal of Public Relations Research, 18(1), 67-89. doi: 10.1207/s1532754xjprr1801_4

Curtin, P. A., \& Gaither, T. K. (2007). International public relations: Negotiating culture, identity and power. Thousand Oaks, California: Sage Publishing.

Cutler, A. (2004). Methodical failure: the use of case study method by public relations researchers. Public Relations Review, 30(3), 365-375. 
Daymon, C., \& Holloway, I. (2011). Qualitative research methods in public relations and marketing communications (2nd edition ed.). Oxon: Routledge.

Dewey, C. (2015). More than 26 million people have changed their Facebook picture to a rainbow flag. Here's why that matters. The Washington Post, (29th June). Retrieved from: https://www.washingtonpost.com/news/the-intersect/wp/2015/06/29/more-than26-million-people-have-changed-their-facebook-picture-to-a-rainbow-flag-heres-whythat-matters/

Du Gay, P., Hall, S., Janes, L., Mackay, H., \& Negus, K. (1997). Doing cultural studies : the story of the Sony Walkman. London: London : Sage Publications in association with the Open University.

Edwards, L. (2012). Exploring the role of public relations as a cultural intermediary occupation. Cultural Sociology, 6(4), 438-454.

Edwards, L. (2013). Institutional Racism in Cultural Production: The Case of Public Relations. The International Journal of Media and Culture, 11(3), 242-256. doi: 10.1080/15405702.2013.810084

Flyvbjerg, B. (2006). Five Misunderstandings About Case-Study Research. Qualitative Inquiry, 12(2), 219-245. doi: 10.1177/1077800405284363

Gaither, T. K., \& Curtin, P. A. (2007). Examining the Heuristic Value of Models of International Public Relations Practice: A Case Study of the Arla Foods Crisis. Journal of Public Relations Research, 20(1), 115-137. doi: 10.1080/10627260701727051

Hall, S. (1973). Encoding and decoding in the television discourse. Centre for Contemporary Cultural Studies (CCCS) Stencilled Occasional Paper, (7). Birmingham.

Hall, S. (1980). Cultural studies: two paradigms. Media, Culture \& Society, 2(1), 57-72. doi: $10.1177 / 016344378000200106$

Hall, S. (1997). Representation: cultural representations and signifying practices London: Sage Publications in association with the Open University.

Han, G., \& Zhang, A. (2009). Starbucks is forbidden in the Forbidden City: Blog, circuit of culture and informal public relations campaign in China. Public Relations Review, 35, 395-401.

Heath, R. L. (1998). New communication technologies: An issues management point of view. Public Relations Review, 24(3), 273-288.

Heine, C. (2015). As \#Scotus Trends, LGBT Group Innovates on Twitter and Enlists Snapchat Stars Adweek, (28th April). Retrieved from: http://www.adweek.com/news/technology/scotus-trends-lgbt-group-runs-first-politicaltwitter-shopping-ads-and-enlists-snapchat-stars-164369

Hodges, C. (2006). "PRP culture" A framework for exploring public relations practitioners as cultural intermediaries. Journal of Communication Management, 10(1), 80-93.

Hofstede, G. (2016). National Culture. Retrieved 16th May 2016, from https://geerthofstede.com/national-culture.html

Hutchins, A., \& Tindall, N. T. (2015). Public Relations and Participatory Culture: Fandom, Social Media and Community Engagement: Routledge.

Introduction to Radian6. (2016). Retrieved 28 April, 2016, from https://resources.docs.salesforce.com/rel1/radian6/enus/static/pdf/MarketingCloudRadian6Introduction.pdf

Jaques, T. (2006). Activist "rules" and the convergence with issue management. Journal of Communication Management, 10(4), 407-420.

Jenkins, H. (2006). Convergence culture : where old and new media collide / Henry Jenkins. New York: New York : New York University Press.

Jenkins, H. (2009). Confronting the challenges of participatory culture: Media education for the 21st century. Cambridge MA: The MIT Press.

Jenkins, L. (2015, 28 June 2015). London Pride parade draws thousands, day after US supreme court ruling. The Guardian. Retrieved from http://www.theguardian.com/uknews/2015/jun/27/london-pride-parade-draws-thousands-day-after-us-supremecourt-ruling 
Kaplan, S. (2014, 14 December 2014). \#HashtagActivismMatters: Some experts see onlineto-IRL change in police protests. Retrieved 27 April, 2016, from https://www.washingtonpost.com/lifestyle/style/hashtagactivismmatters-someexperts-see-online-to-irl-change-in-police-protests/2014/12/14/4d943708-83d4-11e49534-f79a23c40e6c story.html

Macnamara, J. R. (2004). The crucial role of research in multicultural and cross-cultural communication. Journal of Communication Management, 8(3), 322-334.

Matias, J. N. (2015, 28 June 2015). Were All Those Rainbow Profile Photos Another Facebook Study? The Atlantic. Retrieved from http://www.theatlantic.com/technology/archive/2015/06/were-all-those-rainbowprofile-photos-another-facebook-experiment/397088/

Mazzini, R. (2004). A content analysis of activist group use of dialogic tools on the world wide web. (Master of Arts), University of South Florida. Retrieved from http://scholarcommons.usf.edu/etd/1154

McLaughlin, K. (2015). Everybody's dreams should be allowed to come true. Retrieved from http://www.dailymail.co.uk/news/article-3140840/Adorable-kids-break-SupremeCourt-right-declare-sex-marriage-legal-50-states.html

Munshi, D. (1999). Requisitioning variety: Photographic metaphors, ethnocentric lenses, and the divided colours of public relations. Asia Pacific Public Relations Journal, 1(1), 3951.

Pamment, J. (2015). Digital diplomacy as transmedia engagement: Aligning theories of participatory culture with international advocacy campaigns. New Media \& Society, 1 17. doi: $10.1177 / 1461444815577792$

Sanderson, J., Barnes, K., Williamson, C., \& Kian, E. T. (2016). 'How could anyone have predicted that \#AskJameis would go horribly wrong?' public relations, social media, and hashtag hijacking. Public Relations Review, 42(1), 31-37. doi: http://dx.doi.org/10.1016/j.pubrev.2015.11.005

Saxton, G. D., \& Wang, L. (2013). The social network effect: The determinants of giving through social media. Nonprofit and Voluntary Sector Quarterly, 0899764013485159.

Schoenberger-Orgad, M. (2011). NATO's strategic communication as international public relations: The PR practitioner and the challenge of culture in the case of Kosovo. Public Relations Review, 37(4), 376-383. doi: http://dx.doi.org/10.1016/j.pubrev.2011.06.003

Sriramesh, K. (2004). Public Relations in Asia: An Anthology. Singapore: Thomson.

State, B., \& Adamic, L. (2015). The Diffusion of Support in an Online Social Movement: Evidence from the Adoption of Equal-Sign Profile Pictures. Paper presented at the Proceedings of the 18th ACM Conference on Computer Supported Cooperative Work \&\#38; Social Computing, Vancouver, BC, Canada.

Stempeck, M. (2015). Are Uber and Facebook Turning Users into Lobbyists? Harvard Business Review, (11th August). Retrieved from: https://hbr.org/2015/08/are-uberand-facebook-turning-users-into-lobbyists

Terry, V. (2005). Postcard from the Steppes: a snapshot of public relations and culture in Kazakhstan. Public Relations Review, 31(1), 31-36. doi: http://dx.doi.org/10.1016/i.pubrev.2004.11.003

Teves, O. (2015). Filipino LGBT people celebrate Gay Pride, US court decision. The Philippine Star. Retrieved from: http://www.philstar.com/world/2015/06/28/1470918/filipino-lgbt-people-celebrate-gaypride-us-court-decision

Theunissen, P. (2014). Co-creating corporate identity through dialogue: A pilot study. Public Relations Review, 40(3), 612-614. doi: http://dx.doi.org/10.1016/j.pubrev.2014.02.026

Toledano, M., \& McKie, D. (2007). Social integration and public relations: Global lessons from an Israeli experience. Public Relations Review, 33(4), 387-397. doi: http://dx.doi.org/10.1016/j.pubrev.2007.08.013

Valentini, C. (2015). Is using social media "good" for the public relations profession? A critical reflection. Public Relations Review, 41(2), 170-177. 
Valentini, C., \& Kruckeberg, D. (2012). New media versus social media: A conceptualization of their meanings, uses, and implications for public relations. In S. Duhé (Ed.), New media and public relations (pp. 3-12). New York: Peter Lang.

Veil, S. R., Reno, J., Freihaut, R., \& Oldham, J. (2015). Online activists vs. Kraft foods: A case of social media hijacking. Public Relations Review, 41(1), 103-108. doi: http://dx.doi.org/10.1016/i.pubrev.2014.11.017

Watson, T. (2014). Asian Perspectives on the Development of Public Relations: Other Voices: Palgrave Macmillan.

Williams, R. (1961). The Long Revolution. London: Chatto and Windus.

Williams, R. (1981). Culture. London: Fontana Press.

Yin, R. K. (2003). Case study research: Design and method (3rd ed.). Thousand Oaks, CA: Sage. 